\title{
Aplikasi Sistem Akuntansi Pembelian dan Penjualan Barang pada PT Bonar Jaya Adi Perkasa Nusantara Pematangsiantar
}

\author{
Muhammad Ilham $^{1}$, Dedi Suhendro ${ }^{2}$, Arif Maulana $^{3}$ \\ Program Studi Komputerisasi Akuntansi, AMIK Tunas Bangsa, Pematangsiantar \\ Jalan Jend. Sudirman Blok A No 1,2 dan 3 Sumatera Utara \\ Email: ilhamharigost@gmail.com ${ }^{1}$,dedi.su@amiktunasbangsa.ac.id ${ }^{2}$ _arif40145@gmail.com ${ }^{3}$
}

\begin{abstract}
The recording of purchasing and selling transactions at PT Bonar Jaya Adi Perkasa Nusantara Pematangsiantar has not been effective because data management still uses conventional systems and the impact on performance is not in line with expectations because it often experiences errors in making reports. The purpose of this study is to design an application of sales and purchasing accounting systems as a solution to system problems. Research is carried out through the stages of formulating research problems, conducting literature studies, collecting data through observation and interviews, analyzing and designing systems using data flow diagrams and entity relationship diagrams, then testing applications and evaluating the results achieved. The results of this study are in the form of an accounting system for purchasing and selling goods that are able to process purchases and sales of goods more quickly, precisely, accurately and can produce information as needed.
\end{abstract}

Keywords : purchasing and selling transaction, data flow diagram, entity relationship diagram

\begin{abstract}
Abstrak
Pencatatan transaksi pembelian dan penjualan yang dilakukan oleh PT Bonar Jaya Adi Perkasa Nusantara Pematangsiantar belum efektif karena pengelolaan data masih menggunakan sistem konvensional dan berdampak pada kinerja yang tidak sesuai dengan harapan karena sering mengalami kesalahan dalam pembuatan laporan. Tujuan penelitian ini untuk merancang aplikasi sistem akuntansi penjualan dan pembelian barang sebagai solusi permasalahan sistem. Penelitian dilakukan melalui tahapan merumuskan permasalahan penelitian, melakukan studi literature, melakukan pengumpulan data melalui observasi dan wawancara, melakukan analisis dan merancang sistem menggunakan data flow diagram dan entity relationship diagram, selanjutnya melakukan pengujian aplikasi dan mengevaluasi hasil yang dicapai. Hasil penelitian ini berupa aplikasi sistem akuntansi pembelian dan penjualan barang yang mampu mengolah transaksi pembelian dan penjualan barang dengan lebih cepat, tepat, akurat dan dapat menghasilkan informasi sesuai kebutuhan.
\end{abstract}

Kata Kunci : Transaksi penjualan dan pembelian, data flow diagram, entity relationship diagram

(C) 2019 Jurnal Ilmiah MEDIA SISFO

\section{Pendahuluan}

PT Bonar Jaya Adi Perkasa Nusantara merupakan perusahaan swasta yang bergerak dalam bidang usaha hasil bumi padi dan jagung. Setiap harinya perusahaan ini mampu melakukan transaksi jual beli padi dan jagung yang jumlahnya mencapai puluhan ton. Dengan kegiatan yang terbilang sudah cukup padat tersebut, PT Bonar Jaya Adi Perkasa Nusantara tentunya memiliki sistem pembelian dan penjualan Setiap masalah bisnis selalu didasarkan atas informasi-informasi yang melatar belakangi suatu keputusan. Salah satu informasi berupa informasi yang dihasilkan oleh sistem akuntansi. Dalam perusahaan dagang kegiatan usahanya paling aktif adalah membeli dan menjual barang dagangan.

Pengolahan data secara komputerisasi sangat penting dilakukan karena memberikan kontribusi dalam peningkatan kinerja instansi atau perusahaan untuk menunjang sistem pengolahan data berbasis komputerisasi perlu didukung dengan sumber daya manusia yang kompeten dan fasilitas yang memadai. 
Sistem informasi akuntansi merupakan sumber daya atau peralatan yang berguna mengubah data menjadi suatu informasi baik terkomputerisasi kepada pihak manajemen.

Perancangan suatu sistem akuntansi pembelian dan penjualan barang sangat dibutuhkan sesuai dengan perkembangan teknologi informasi sekarang ini karena kegiatan jual beli yang dilakukan dengan manual sudah mulai ditinggalkan dan beralih kepada sistem terkomputerisasi. Sistem komputerisasi diharapkan dapat meningkatkan produktivitas, efisiensi kerja, serta merupakan pilihan yang sangat tepat apabila perusahaan menerapkan sistem komputerisasi dalam melaksanakan aktivitasnya. Dalam sistem akuntansi terdapat sistem pengolahan informasi akuntansi, sejak data mulai direkam dalam dokumen hingga disajikan dalam bentuk laporan keuangan.

Sistem akuntansi yang terkomputerisasi tidak hanya digunakan untuk mencatat transaksi keuangan yang telah terjadi saja, namun memiliki peran yang besar dalam melaksanakan bisnis perusahaan. Bahkan dalam bisnis perusahaan tertentu, sistem akuntansi merupakan alat yang digunakan untuk melaksanakan bisnis utama perusahaan. Penulis ingin membangun dan mengembangkan sebuah sistem akuntansi yang digunakan untuk mengelola data pembelian dan penjualan barang. Untuk menghindari kerangkapan data digunakan Relasi Antar Tabel (RAT) dan Entity Relationship Diagram (ERD) serta Data Flow Diagram (DFD) untuk melihat alur sistem. Dalam membangun dan mengembangkan sistem ini digunakan Microsoft Visual Studio 2010 dan MySQL Database.

\section{Tinjuan Pustaka}

\subsection{Sistem Akuntansi}

Sistem akuntansi adalah pengorganisasian dokumen atau formulir, catatan akuntansi yang dalam hal ini adalah jurnal, dan laporan dari masing-masing bagian yang dikoordinasikan sedemikian rupa untuk menyediakan informasi keuangan yang dibutuhkan oleh manajemen [1]. Sistem informasi akuntansi adalah sumber daya manusia atau peralatan yang berguna mengubah data menjadi suatu informasi baik terkomputerisasi ataupun manual kepada pihak manajemen [2]. Sistem akuntansi nantinya akan menghasilkan berupa laporan keuangan. Laporan keuangan pada dasarnya bertujuan untuk melaporkan kegiatan-kegiatan yang telah dilakukan oleh perusahaan sekaligus mengevaluasi keberhasilan strategi perusahaan untuk mencapai tujuan dari perusahaan [3].

Tujuan Sistem Akuntansi adalah 1). Untuk menyediakan informasi bagi pengelola kegiatan usaha baru, 2). Untuk memperbaiki informasi yang dihasilkan oleh sistem yang sudah ada, baik mengenai mutu, ketepatan penyajian maupun informasinya, 3). Untuk memperbaiki pengendalian akuntansi dan pengecekan intern, yaitu untuk memperbaiki tingkat keandalan (reliability) informasi akuntansi dan untuk menjadikan catatan lengkap mengenai pertanggungjawaban dan perlindungan kekayaan perusahaan [1].

Unsur Sistem Akuntansi adalah 1). Formulir dan dokumen, 2). Keberadaan catatan harian atau jurnal, 3). Adanya pembukuan, 4). Laporan, 5). Prosedur dan Kontrol [1].

Fungsi Sistem Akuntasi adalah 1). Sistem akuntansi digunakan sebagai alat untuk melindungi dan mengkontrol aset perusahaan, 2). Sistem akuntansi dapat digunakan sebagai acuan menghasilkan informasi sebagai alat pengambil keputusan, 3). Sistem akuntansi dapat berbentuk data-data keuangan maupun non keuangan [1] .

\subsection{Pembelian dan Penjualan}

Pembelian merupakan kegiatan yang dilakukan untuk pengadaan barang yang dibutuhkan perusahaan dalam menjalankan usahanya dimulai dari pemilihan sumber sampai memperoleh barang. Pembelian didefinisikan sebagai usaha untuk memenuhi kebutuhan atas barang atau jasa yang diperlukan oleh perusahaan dan dapat diterima tepat waktunya dengan mutu yang sesuai serta harus yang menguntungkan [4]. Standar Akuntansi Keuangan (SAK) dalam Pernyataan Standart Akuntansi Keuangan No 23 (Revisi 2010) menyatakan, penjualan barang meliputi barang yang diproduksi perusahaan untuk dijual dan barang yang dibeli untuk dijual kembali seperti barang yang dibeli pengecer atau tanah atau properti lain yang dibeli untuk dijual kembali.

Aktivitas penjualan merupakan pendapatan utama perusahaan karena jika aktivitas penjualan produk atau jasa tidak dikelola dengan baik maka secara langsung dapat merugikan perusahaan. Hal ini dapat 
disebabkan karena sasaran penjualan yang diharapkan tidak tercapai dan pendapatan pun akan berkurang [5]. Menurut Pernyataan Standart Akuntansi Keuangan (PSAK) No. 14 tahun 2008 persediaan adalah aset 1). Tersedia untuk dijual dalam kegiatan usaha biasa, 2). Proses produksi untuk penjualan tersebut, 3). Bentuk bahan atau perlengkapan untuk digunakan dalam proses produksi atau pemberian jasa.

\subsection{Penelitian Terdahulu}

Penelitian dengan judul Rancang Bangun Aplikasi Penjualan dan Pembelian Barang pada Koperasi Kartika Samara Grawira Prabumulih. Aplikasi Penjualan dan Pembelian Barang di Koperasi Kartika Samara Grawira Prabumulih berbasis website ini bertujuan untuk mempermudah kerja Pegawai melakukan transaksi penjualan maupun pembelian. Penjualan tidak hanya dilakukan di Koperasi saja dan mampu memasarkan barang-barang secara luas [6].

Hasil penelitian dengan judul Aplikasi Pembelian dan Penjualan Barang Dagang pada CV Gemilang Muliatama Cikarang, adanya aplikasi pembelian dan penjualan barang dagang maka administrator lebih terbantu mengolah data barang, data customer dan data supplier sehingga pegawai memiliki kemudahan dalam mengelola pembukuan maka penyajian laporan menjadi lebih mudah dan terperinci karena hanya perlu menggunakan salah satu fasilitas yang ada pada aplikasi ini [7].

Berbeda dengan penelitian dengan judul Rancang Bangun Aplikasi Penjualan dan Pembelian Berbasis Web pada Apotek Neofarma Sanggau ini berjalan sesuai dengan fungsinya yaitu dapat melakukan manajemen data obat, data pengguna, data dokter, dan data pemasok. Karyawan apotek dapat melakukan transaksi penjualan dan pembelian obat serta mencetak laporan penjualan dan pembelian obat. sehingga dapat mempermudah dan memperlancar kegiatan transaksi pada Apotek Neofarma Sanggau serta dapat memberikan informasi pemberitahuan obat yang akan habis, obat yang sudah habis, obat yang akan kadaluarsa, dan obat yang sudah kadaluarsa. Dengan adanya sistem ini karyawan apotek lebih terbantu dalam melakukan restok obat [8].

Penelitian yang disampaikan dalam Seminar Nasional Teknologi Informasi dan Multimedia yang berjudul Perancangan Sistem Penjualan dan Pembelian Sparepat Kendaraan Bermotor pada Toko Ahmad Service, dengan adanya aplikasi ini pihak Toko Ahmad Service tidak lagi mengalami kesulitan dalam mengolah penjualan dan pembelian barangsehari - harinya sehingga tersedianya laporan penjualan, pembelian dan stok barang yang dapat dengan mudah diketahui [9].

Penelitian dengan judul penelitian Implementasi Akuntansi Sistem Pembelian dan Penjualan Obat dengan Menggunakan Aplikasi MYOB Accounting pada Praktek Kedokteran adanya sistem penjualan dan pembelian secara komputerisasi pengolahan data, penyajian informasi pembelian akan lebih cepat, serta keakuratan data akan lebih terjamin karena tempat atau media penyimpanan lebih terjaga karena dengan sistem imformasi penjualan dan pembelian ini dapat diperoleh data yang akurat seandainya diperlukan dalam waktu singkat, dan dapat membantu kinerja dalam meningkatkan penjualan dan pembelian sehingga memudahkan dalam membuat informasi penjualan dan pembelian yang diinginkan [10].

\section{Metodologi}

Tahapan-tahapan dalam penelitian ini dibutuhkan alur kerja yang dapat memperjelas tentang langkahlangkah yang di laksanakan guna menyelesaikan kendala-kendala dalam proses penelitian. Adapun alur kerja penelitian yang digunakan yaitu :

1. Perumusan Masalah

Pada tahap ini penulis merumuskan ruang lingkup masalah yang akan dibahas pada penelitian ini.

2. Studi Literatur

Pada tahap ini penulis melakukan apa yang disebut dengan kajian pustaka yaitu mempelajari bukubuku referensi dan paper jurnal.

3. Pengumpulan Data

Pada tahap ini penulis melakukan pengumpulan data, pengumpulan data merupakan tahapan dalam proses penelitian yang penting dimana penulis harus mendapatkan data yang di butuhkan dalam merancang sistem. Mulai dari observasi yang secara langsung diperoleh penulis dari PT Bonar Jaya Adi Perkasa Nusantara Pematangsiantar untuk mendapatkan data yang diperlukan sampai interview dimana penulis melakukan proses tanya jawab atau wawancara secara langsung dengan pegawai yang menangani pembelian dan penjualan barang di PT Bonar Jaya Adi Perkasa Nusantara Pematangsiantar 
guna mengumpulkan informasi dan data-data yang diperlukan untuk menyelesaikan masalah yang ada.

4. Analisa dan Perancangan

Pada tahap ini dilakukan analisis dan perancangan sistem informasi sesuai dengan kebutuhan

5. Pengujian

Pada tahap ini dilakukan pengujian rancangan aplikasi telah di buat oleh penulis, untuk membuktikan bahwa rancangan aplikasi yang di buat telah valid.

6. Evaluasi

Pada tahap ini penulis melakukan evaluasi hasil rancangan aplikasi, dimana penulis mengkaji dan memberikan penilaian.

\section{Hasil dan Pembahasan}

\subsection{Rancangan Proses}

Rancangan proses dimodelkan dengan Data Flow Diagram (DFD). Data Flow Diagram (DFD) berfungsi untuk menggambarkan alur kerja sistem atau cara kerja sistem secara garis besar. Perancangan Data Flow Diagram (DFD) dilakukan secara terperinci, yang diuraikan berdasarkan proses alur kerja masing masing. Rancangan proses berisikan diagram konteks dan Data Flow Diagram.

Penggambaran diagram konteks pada sistem yang dirancang oleh penulis, dapat dilihat pada gambar 1 dibawah ini :

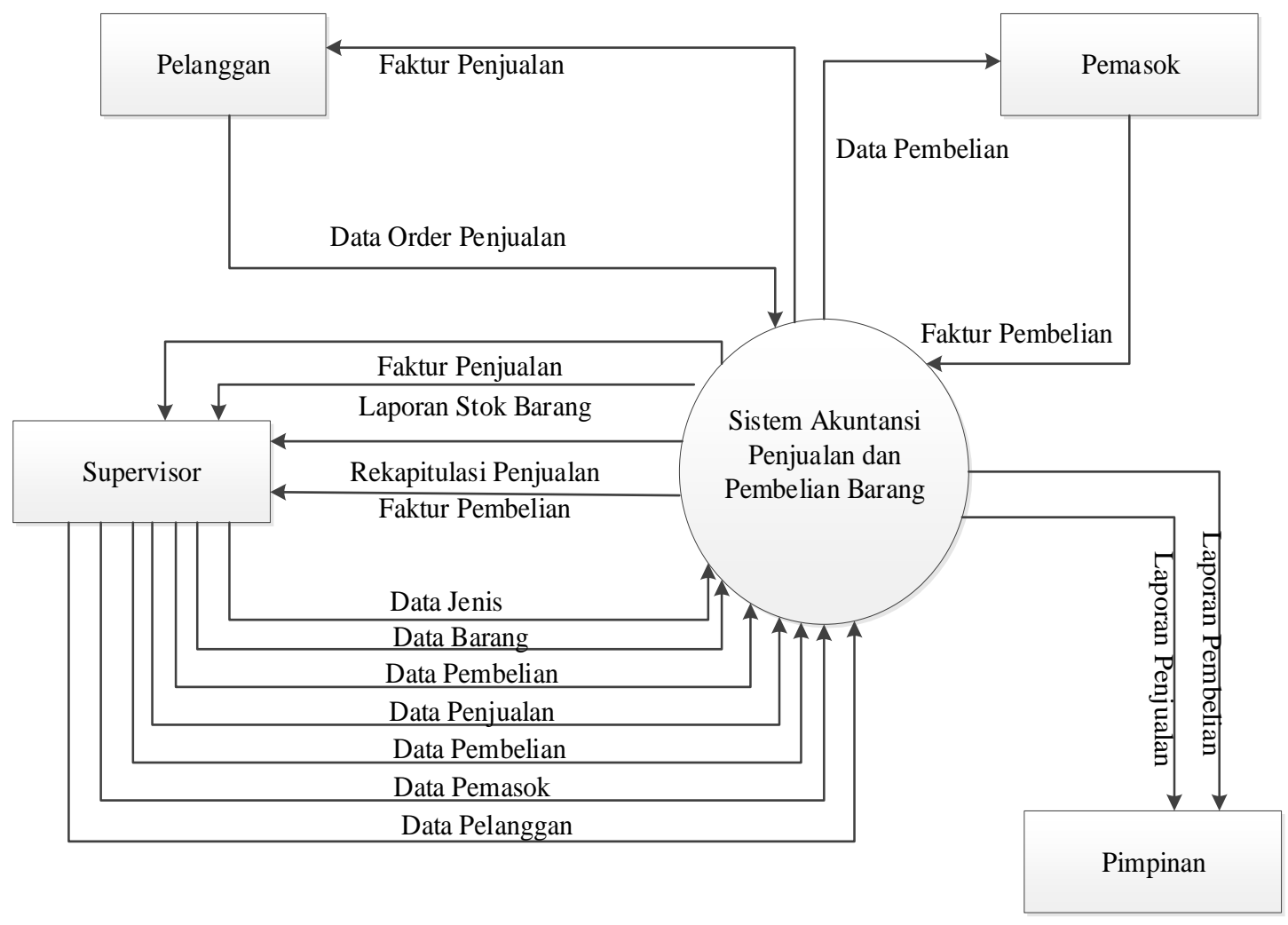

Gambar 1. Diagram Konteks

Data Flow Diagram (DFD) aliran data di antara komponen sistem-sistem, tujuan, sumber data, sampai penyimpanan data. 


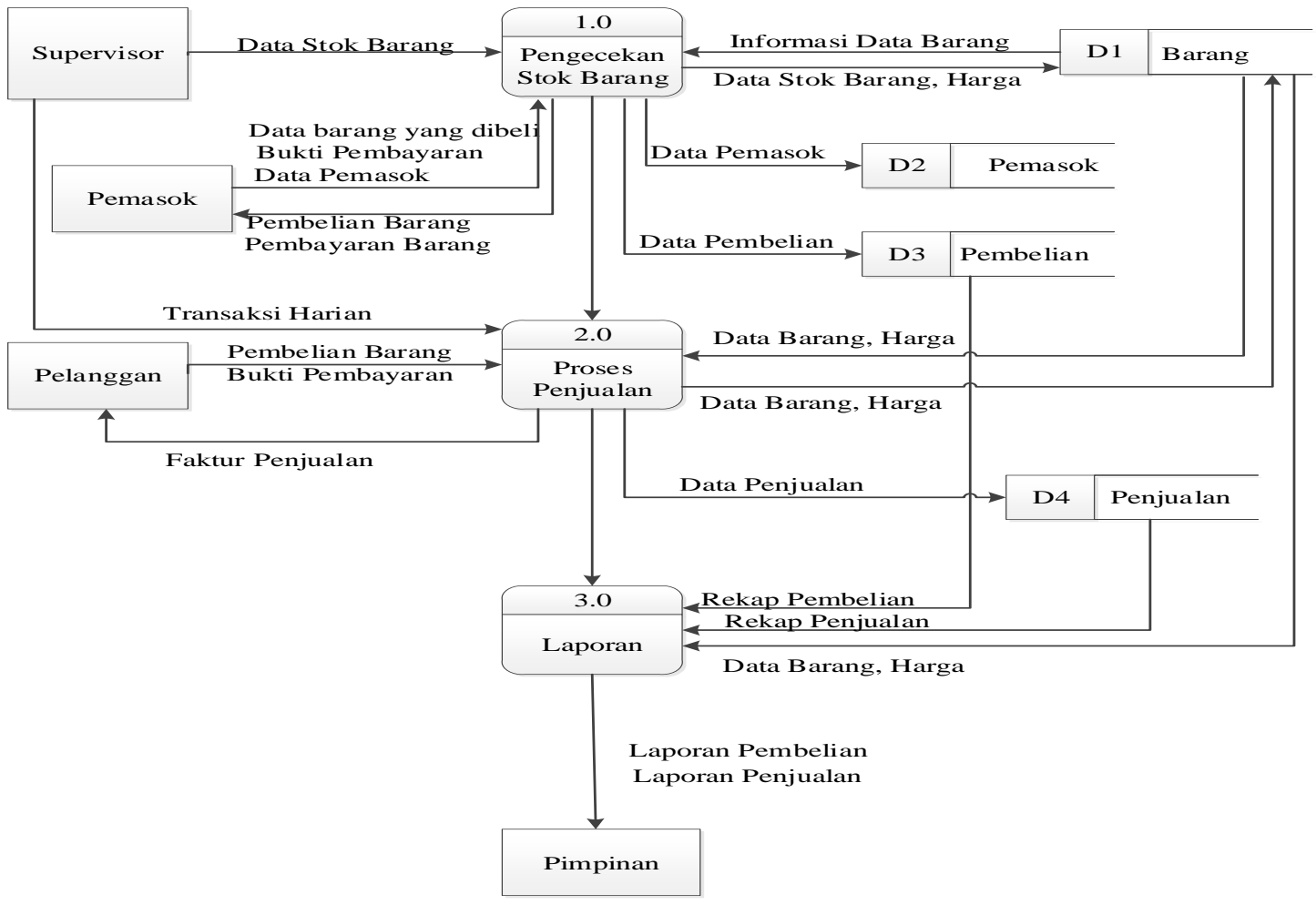

Gambar 2. Data Flow Diagram (DFD) Level 0

\subsection{Rancangan Basis Data}

Bentuk dari Entity Relation Diagram dari Aplikasi Sistem Akuntansi Pembelian dan Penjualan barang pada PT Bonar Jaya Adi Perkasa Nusantara Pematangsiantar seperti gambar di bawah ini:

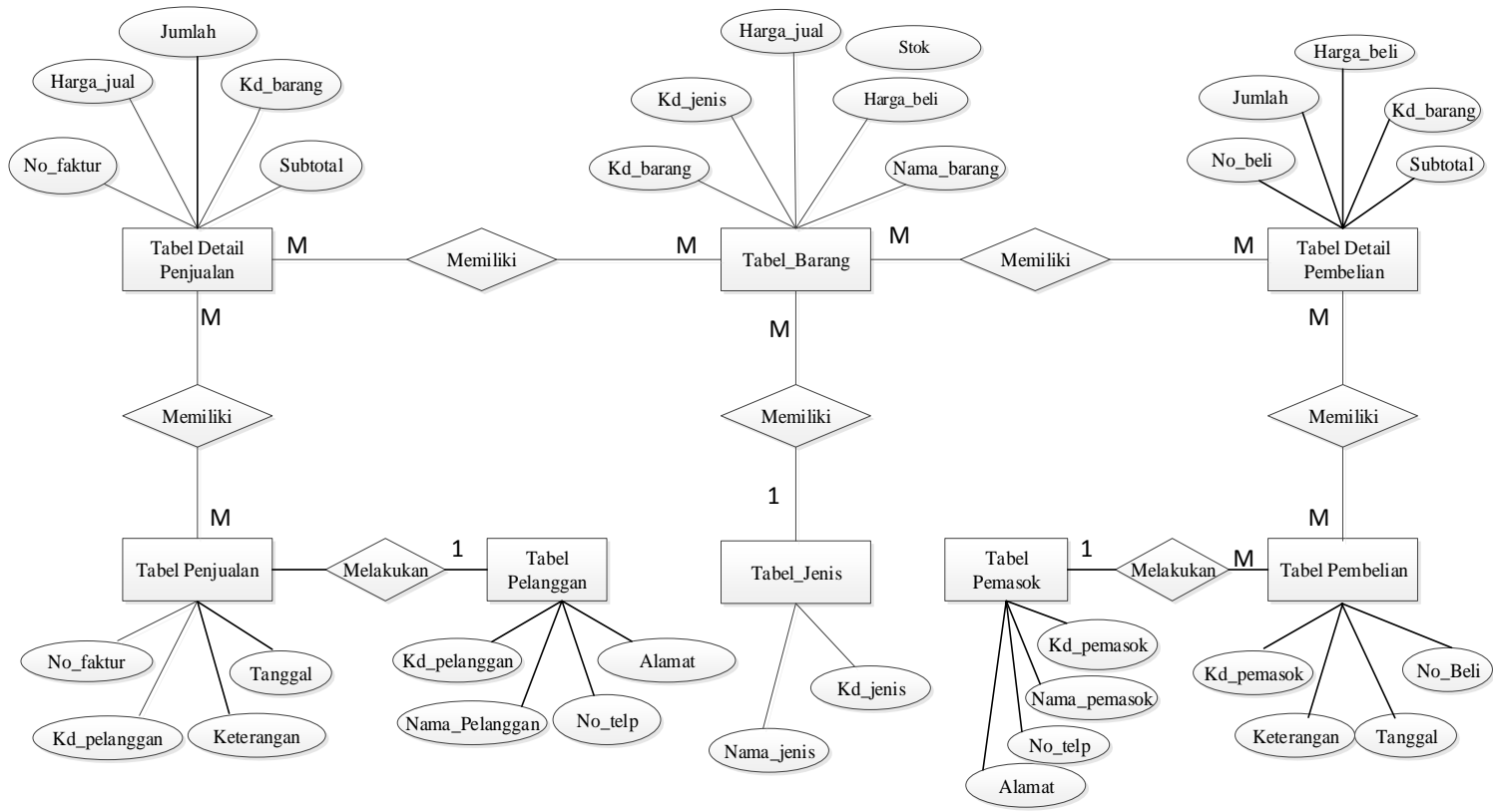

Gambar 3. Entitas Relation Diagram

\subsection{Hasil Implementasi dan Pembahasan}

Pada tahapan ini merupakan tahapan dimana didapatkan hasil dari perancangan layout yang telah diimplementasikan kedalam program yang dibuat dengan menggunakan Microsoft Visual Studio 2010. 
1. Tampilan menu pembelian

Form pembelian dapat dijalankan melalui menu transaksi pada halaman menu utama, kemudian pilih submenu pembelian. Maka form pembelian akan muncul seperti pada gambar 4 di bawah ini :

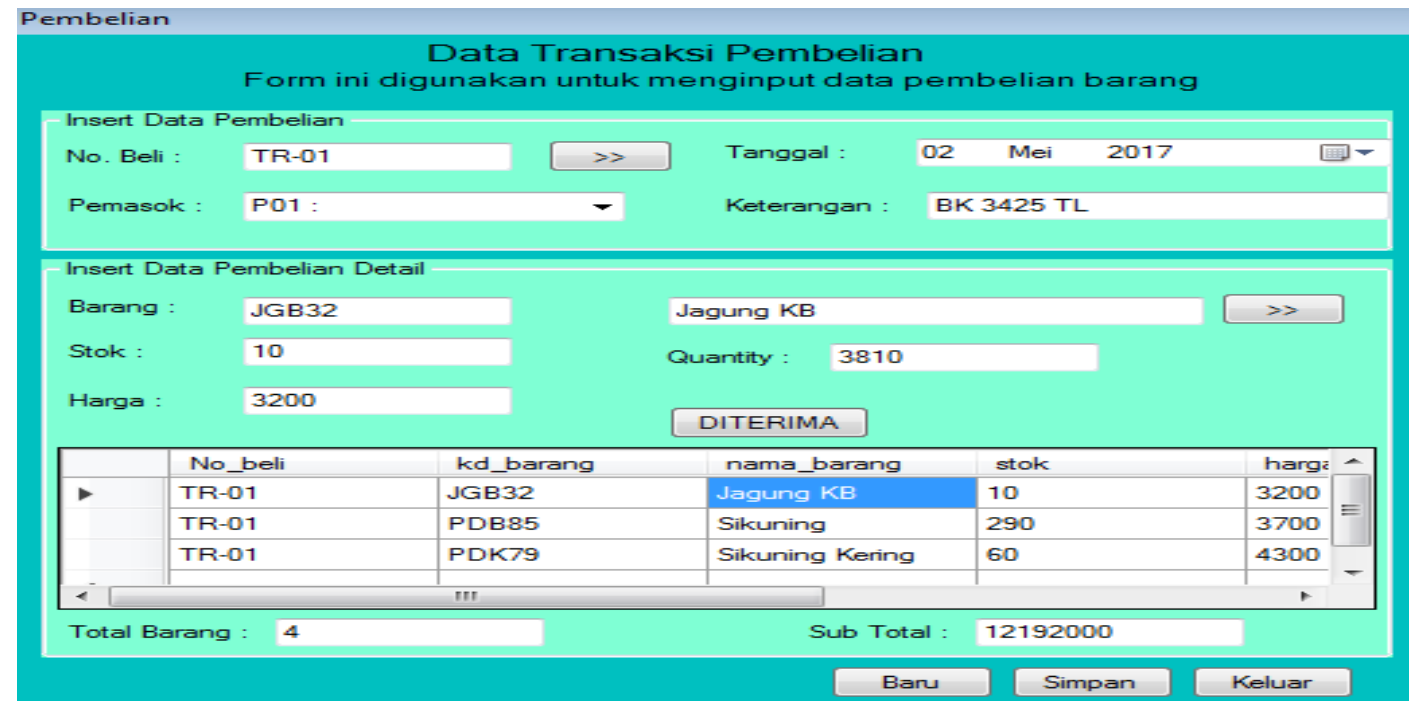

Gambar 4. Form Pembelian

Apabila data telah selesai diisi, pilih perintah save untuk menyimpan data, dan pilih perintah new jika ingin membuat data baru. Data yang telah berhasil disimpan, akan ditampung dan muncul pada DataGridView. Jika ingin melakukan update atau edit pada data yang telah tersimpan, pilihlah data yang akan diubah dan klik pada DataGridView, secara otomatis data akan muncul kembali pada kotak isian. Pilih perintah save jika telah selesai mengubah isi data. Perintah delete digunakan untuk menghapus data, dengan cara pilih data yang akan dihapus pada DataGridView lalu klik, kemudian pilih perintah delete. Pilih perintah close jika ingin keluar dari halaman form pembelian.

2. Tampilan menu penjualan

Form penjualan dapat dijalankan melalui menu transaksi pada halaman menu utama, kemudian pilih submenu penjualan. Maka form penjualan akan muncul seperti pada gambar 5 berikut:

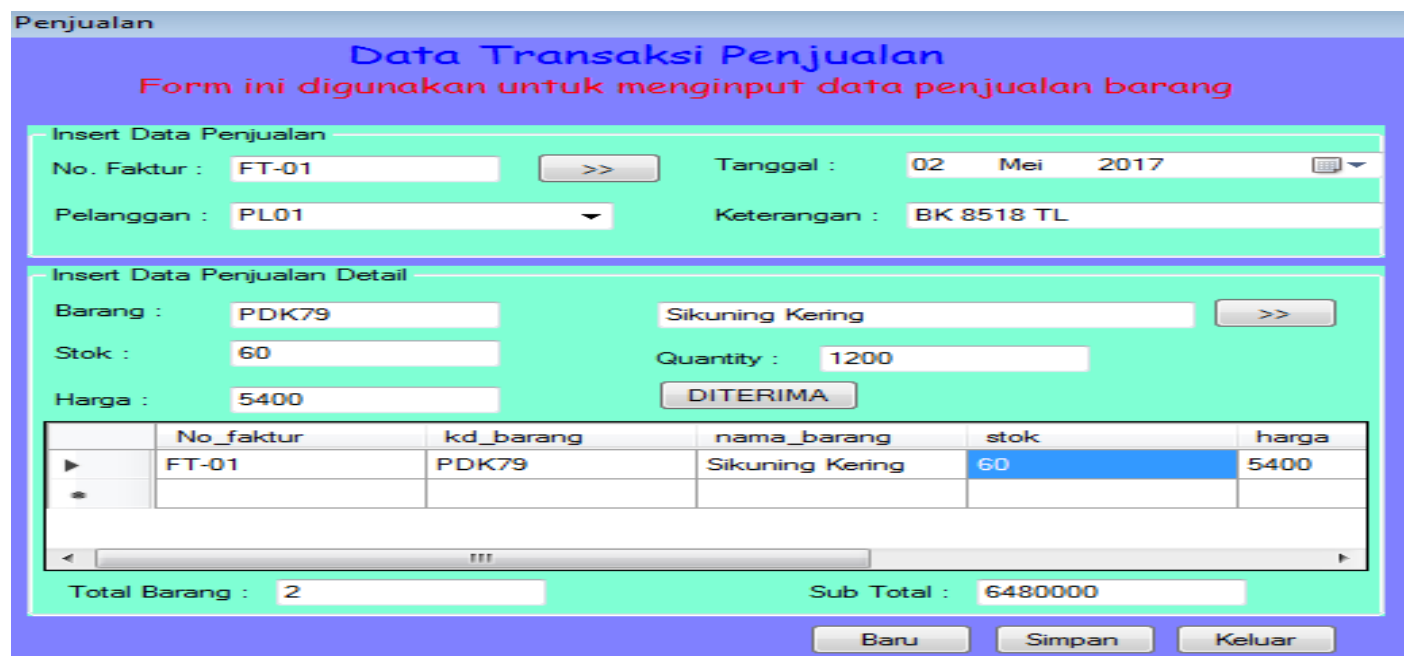

Gambar 5. Form Penjualan

Apabila data telah selesai diisi, pilih perintah simpan untuk menyimpan data, dan pilih perintah new jika ingin membuat data baru. Data yang telah berhasil disimpan, akan ditampung dan muncul pada 
DataGridView. Jika ingin melakukan update atau edit pada data yang telah tersimpan, pilihlah data yang akan diubah dan klik pada DataGridView, secara otomatis data akan muncul kembali pada kotak isian. Pilih perintah save jika telah selesai mengubah isi data. Perintah delete digunakan untuk menghapus data, dengan cara pilih data yang akan dihapus pada DataGridView lalu klik, kemudian pilih perintah delete. Pilih perintah close jika ingin keluar dari halaman form penjualan.

3. Laporan Penjualan

Form laporan penjualan dihasilkan dari transaksi yang telah kita lakukan pada menu form penjualan dan untuk menghasilkan laporan dapat dijalankan melalui menu laporan pada halaman menu utama, kemudian pilih submenu laporan penjualan. Maka form penjualan barang akan muncul seperti gambar 6 .

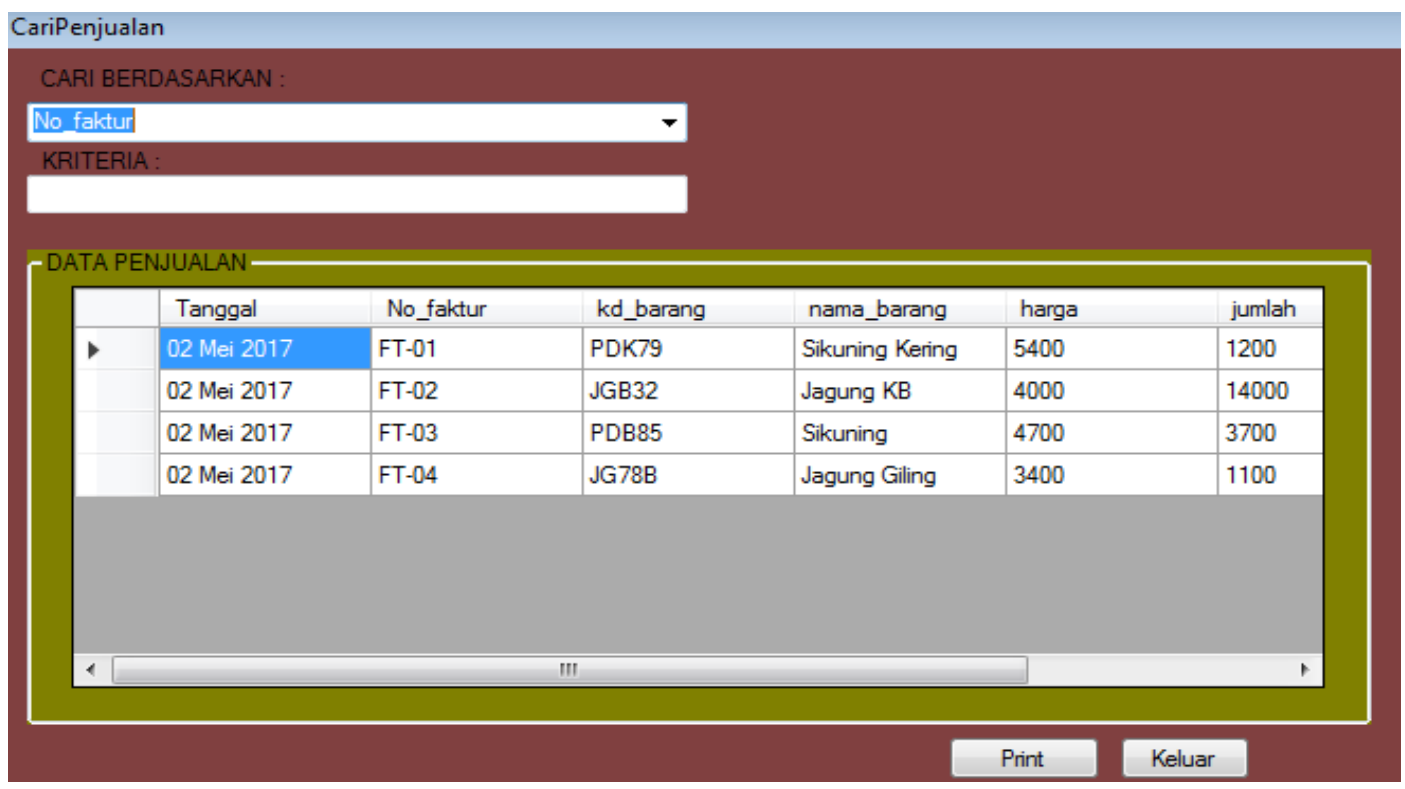

Gambar 6. Form Cetak Laporan Penjualan

Untuk melihat preview laporan penjualan klik button cetak untuk mencetak data, sehingga akan muncul tampilan atau preview laporan penjualan seperti gambar 7 di bawah ini :

\begin{tabular}{|c|c|c|c|c|c|c|}
\hline \multicolumn{7}{|c|}{$\begin{array}{l}\text { PT. Bonar Jaya Adi Perkasa Nusantara } \\
\text { Jalan Medan Km 5,5 } \\
\text { Pematangsiantar }\end{array}$} \\
\hline \multicolumn{7}{|c|}{$\begin{array}{c}\text { Laporan Penjualan } \\
\text { Bulan : Mei } 2017\end{array}$} \\
\hline Tanggal & NoFaktur & Kode Barang & Nama Barang & Harga & Jumlah & Subtotal \\
\hline 02 Mei 2017 & FT-01 & PDK 79 & Sikuning Kering & $\operatorname{Rp} 5.400$ & 1.200 & $\mathrm{Rp} 6.480 .000$ \\
\hline 02 Mei 2017 & FT-02 & JGB32 & Jagung KB & Rp 4.000 & 14.000 & Rp 56.000 .000 \\
\hline 02 Mei 2017 & FT-03 & PDB85 & Sikuning & Rp 4.700 & 3.700 & Rp 17.390 .000 \\
\hline 02 Mei 2017 & FT-04 & JG78B & Jagung Giling & Rp 3.400 & 1.100 & Rp 3.740 .000 \\
\hline & & & & Pema & ntar, 3 & -Agustus-2018 \\
\hline
\end{tabular}

Gambar 7. Preview Laporan Penjualan 
4. Laporan Pembelian

Form laporan pembelian dihasilkan dari transaksi yang sudah dilakukan user pada menu pembelian dan untuk menghasilkan laporan pemebelian dapat dijalankan melalui menu laporan pada halaman menu utama, kemudian pilih submenu laporan pembelian. Maka form pembelian barang akan muncul seperti gambar 8 .

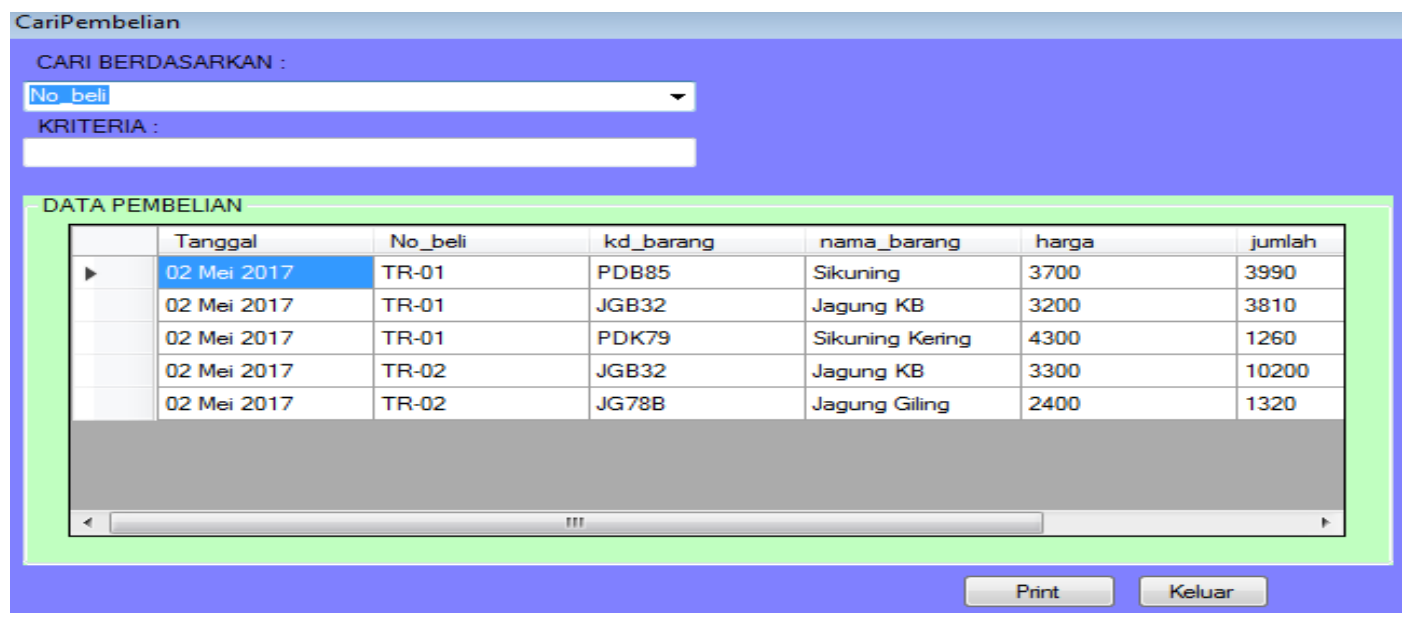

Gambar 8. Laporan Pembelian

Untuk menghasilkan preview cetak laporan pembelian klik button cetak untuk mencetak data, sehingga akan muncul tampilan atau preview laporan pembelian seperti gambar 9 di bawah ini :

\section{PT. Bonar Jaya Adi Perkasa Nusantara \\ Jalan Medan $\mathrm{Km}$ 5,5 \\ Pematangsiantar}

Laporan Pembelian

Bulan : Mei 2017

\begin{tabular}{|c|c|c|c|c|c|c|}
\hline Tanggal & No Beli & Kode Barang & Nama Barang & Harga & Jumlah & Subtotal \\
\hline 02 Mei 2017 & TR-01 & PDB85 & Sikuning & $\operatorname{Rp} 3.700$ & 3.990 & Rp 14.763.000 \\
\hline 02 Mei 2017 & TR-01 & JGB32 & Jagung KB & $\operatorname{Rp} 3.200$ & 3.810 & Rp 12.192 .000 \\
\hline 02 Mei 2017 & TR-01 & PDK 79 & Sikuning Kerin & $\operatorname{Rp} 4.300$ & 1.260 & Rp 5.418.000 \\
\hline 02 Mei 2017 & TR-02 & JGB32 & Jagung $\mathrm{KB}$ & Rp 3.300 & 10.200 & $\operatorname{Rp} 33.660 .000$ \\
\hline 02 Mei 2017 & TR-02 & $\mathrm{JG} 78 \mathrm{~B}$ & Jagung Giling & $\operatorname{Rp} 2.400$ & 1.320 & $\mathrm{Rp} 3.168 .000$ \\
\hline
\end{tabular}

Diketahui :

Manager Keuangan Supervisor

Gambar 9. Preview Laporan Pembelian

\section{Kesimpulan}

Sistem akuntansi pembelian dan penjualan barang PT Bonar Jaya Adi Perkasa Nusantara Pematangsiantar dalam proses penginputan dan pencarian data pembelian dan penjualan lebih efektif dan efesien serta tidak terjadi lagi penggandaan data maupun kehilangan data sehingga memberikan kemudahan pada supervisor memeriksa dan mengaudit laporan baik laporan pembelian dan penjualan secara akurat, terperinci serta tepat waktu. 


\section{Daftar Rujukan}

[1] Janua Nur Anisyah, Moch.Dzulkirom, and Dwiatmanto, "Analisis Sistem dan Prosedur Penjualan dan Penerimaan Kas dalam Mendukung Pengendalian Intern (Studi pada PT Astra Internasional,Tbk Auto 2000 Kediri Suharmadji )," J. Adm. Bisnis (JAB)|, vol. 52, no. 1, pp. 9099, 2017.

[2] M. Viola, R. K. Ekawati, and T. Wijaya, "Analisis Dan Perancangan Sistem Informasi Akuntansi Penjualan Dan Persediaan,” J. Terap. Teknol. Inf., vol. 1, no. 2, pp. 155-164, 2017.

[3] D. Suhendro, "Analisis Profitabilitas dan Likuiditas Untuk Menilai Kinerja Keuangan Pada PT Siantar Top Tbk," Hum. Falah, vol. 4, no. 2, pp. 218-235, 2017.

[4] Isnadi, B. E. Purnama, and S. Iriani, "Pembangunan Aplikasi Pembelian dan Penjualan Barang Pada Toko Ritzca Elektronik Punung,” J. Comput. Sci. Speed, vol. 9, no. 3, 2012.

[5] K. D. Deti and H. Mulyono, "Informasi Penjualan Dan Pemesanan Plywood Berbasiskan Web Pada PT Kumpeh,” J. Manaj. Sist. Inf., vol. 2, no. 1, p. 304, 2017.

[6] A. N. Nurhayati, A. Josi, and N. A. Hutagalung, "Rancang Bangun Aplikasi Penjualan dan Pembelian Barang pada Koperasi Kartika Samara Grawira Prabumulih,” J. Teknol. dan Inf., vol. 7, no. 2, pp. 13-23, 2018.

[7] I. Sholikhah, M. Sairan, and N. O. Syamsiah, "Aplikasi Pembelian dan Penjualan Barang Dagang pada CV Gemilang Muliatama Cikarang,” J. Tek. Komput. AMIK BSI, vol. III, no. 1, pp. 16-23, 2017.

[8] P. Noviandhiny, "Rancang Bangun Aplikasi Penjualan dan Pembelian Berbasis Web pada Apotek Neofarma Sanggau," J. Sist. dan Teknol. Inf., vol. 6, no. 3, pp. 125-130, 2018.

[9] H. Kurniawan, "Perancangan Sistem Penjualan dan Pembelian Sparepat Kendaraan Bermotor pada Toko Ahmad Service," in Seminar Nasional Teknologi Informasi dan Multimedia 2015, 2015, pp. 6-8.

[10] A. Wahyuningsih, "Implementasi Akuntansi Sistem Pembelian dan Penjualan Obat dengan Menggunakan Aplikasi MYOB Accounting pada Praktek Kedokteran," J. Sisfokom (Sistem Inf. dan Komputer), vol. 2, no. 2, pp. 5-11, 2013. 